\title{
Akt-1 Expression Level Regulates CNS Precursors
}

\author{
Amy D. Sinor and Laura Lillien \\ Department of Neurobiology and Pittsburgh Cancer Institute, University of Pittsburgh School of Medicine, Pittsburgh, Pennsylvania 15261
}

\begin{abstract}
Although most cells in the embryonic mouse cortex express the serine-threonine kinase Akt-1, a small population of progenitors expresses Akt-1 protein at a higher level. To determine the functional significance of this difference, we used a retrovirus to increase Akt-1 expression in cortical progenitors. Increased Akt expression enhanced Akt activation after growth factor stimulation of progenitors. In vivo, it promoted retention in progenitor layers, the ventricular zone and subventricular zone. In vitro, it enhanced proliferation and survival, but did not impair migration. Moreover, it increased the proportion of stem cells, defined by a self-renewal assay. These effects did not depend on the Akt substrate p21(Cip1). In contrast, rapamycin, an inhibitor of mTOR (mammalian target of rapamycin), altered effects of elevated Akt-1 selectively: it eliminated the increase in stem cells and reduced the proliferative response, but had no effect on survival. The ability of elevated Akt-1 to increase the self-renewing population therefore depends on a rapamycin-sensitive mechanism (presumably inhibition of mTOR activity) but not on $\mathrm{p} 21$ (Cip1), and can be distinguished from its effects on the proliferation and survival of other types of progenitors. Our findings suggest that expression of a high level of Akt-1 by a subpopulation of cortical progenitors biases their responses to extrinsic signals to increase their survival, proliferation, and/or self-renewal. Heterogeneity in Akt-1 level among progenitors could therefore allow cells that share a microenvironment to respond differently to the same extrinsic signals.
\end{abstract}

Key words: mTOR; p21(Cip1); rapamycin; FGF2; EGF; cortex

\section{Introduction}

The developing CNS contains multiple progenitor populations (for review, see Temple, 2001). Although they differ in their phenotypic and proliferative potentials, subtypes of CNS progenitors often share a microenvironment. This raises questions about the mechanisms that allow some progenitors to continue to divide while neighboring cells stop dividing and differentiate at appropriate times during development. Some molecular markers that distinguish CNS progenitor subsets have been reported (Geschwind et al., 2001; Luo et al., 2002). Heterogeneity in the level of expression of selected molecules has also been noted (Lillien, 1995; Burrows et al., 1997). Both qualitative and quantitative molecular differences among progenitors are likely to contribute to their ability to respond differently to extrinsic signals that influence their proliferation and differentiation.

Several extrinsic factors that act on progenitors and stem cells in the embryonic and adult CNS have been identified. For example, fibroblast growth factor 2 (FGF2), epidermal growth factor (EGF), and insulin-insulin-like growth factor 1 (IGF-1) increase the size of the progenitor and stem cell pools (Reynolds et al., 1992; Kilpatrick and Bartlett, 1993; Ray et al., 1993; Arsenijevic et al., 2001). In contrast, erythropoietin reduces the number of stem cells (Shingo et al., 2001). These factors are pleiotropic. They

Received Feb. 9, 2004; revised Aug. 3, 2004; accepted Aug. 12, 2004.

This work was supported by National Institutes of Health Grant R01 NS038306. We thank Alexandra Gulacsi and Drs. Pat Levitt, Jane Viti, Damira Caric, Damon Anderson, Bethann McLaughlin, and Sabrina Mcllwrath for their advice and Kristi Weigle, Jenny Halfhill, and Carl Engman for technical assistance.

Correspondence should be addressed to Laura Lillien, Department of Neurobiology and Pittsburgh Cancer Institute, University of Pittsburgh School of Medicine, W1454 Biomedical Science Tower, Pittsburgh, PA 15261. E-mail: lillien+@pitt.edu.

D01:10.1523/JNEUROSCI.1470-04.2004

Copyright $\odot 2004$ Society for Neuroscience $\quad$ 0270-6474/04/248531-11\$15.00/0 could regulate the number of stem cells by selective survival or proliferation, or by controlling the choice to remain a stem cell or "differentiate" into a more restricted progenitor. They activate many intracellular transduction pathways, but it is not known which pathway or pathways are critical for survival, proliferation, or maintenance of neural stem cells.

Some cell-intrinsic molecules that regulate progenitor and stem cell number have also been identified. For example, mice lacking the Notch effecter HES-1 (hairy enhancer of split-1) (Nakamura et al., 2000b) have fewer stem cells, whereas mice lacking the phosphatase and tensin homolog tumor suppressor gene (PTEN) have more stem cells (Groszer et al., 2001). PTEN negatively regulates the activity of several proteins (Li and Sun, 1998; Sun et al., 1999; Nakamura et al., 2000a), but the target of PTEN that normally serves to increase the proportion of neural stem cells has not been identified. One protein whose activity is negatively regulated by PTEN is the serine-threonine kinase Akt (Stambolic et al., 1998). In contrast, FGF2, insulin-IGF-1, and EGF increase Akt activity (Alessi et al., 1996a; Chaudhary and Hruska, 2001). Akt is normally expressed by CNS progenitors (Owada et al., 1997). It was initially characterized as a mediator of anti-apoptotic signaling in a variety of cells, including CNS neurons (Dudek et al., 1997; Haseyama et al., 1999). More recent work has identified additional Akt substrates that regulate proliferation, including p21(Cip1) (Rossig et al., 2001), tuberous sclerosis complex-2 (tsc2) (Manning et al., 2002), and mTOR (Nave et al., 1999).

These data raised the possibility that Akt might normally be important for regulating the behavior of neural progenitors. We noted that Akt-1 was expressed at a higher level in a subset of progenitors in embryonic mouse cortex. To determine the functional significance of this difference, we increased expression of 
wild-type Akt-1 in cortical progenitors in vivo and in vitro using a replication incompetent retrovirus to selectively infect progenitors. We then assessed the effects of elevated Akt-1 expression on survival, proliferation, migration, and self-renewal. To begin to address the molecular mediators of Akt- 1 in cortical progenitors, we focused on $\mathrm{p} 21$ (Cip1) and mTOR and asked whether either was required for specific responses to elevated Akt- 1 .

\section{Materials and Methods}

Retroviruses. The cDNAs for wild-type Akt-1 and dominant-negative (dn)-Akt (K179M) were purchased from Upstate Biotechnology (Lake Placid, NY). Akt-1 and dn-Akt coding sequences were subcloned into pLig-ns (Lillien, 1995) for coexpression of $\beta$-geo ( $\beta$-gal plus neomycinphosphotransferase) and pLie (Viti et al., 2003) for coexpression of green fluorescent protein (GFP). Virus was made from clones of transfected $\Psi 2$ cells selected in G418 (Invitrogen, Grand Island, NY). Clones of $\Psi 2$ producer cells were selected by screening for expression of viral genes and production of high titer virus. Viruses with titers of $1-2 \times 10^{7} \mathrm{cfu} / \mathrm{ml}$ were selected for experiments in vitro and in vivo.

To confirm coexpression of virally transduced genes, $3 \mathrm{~T} 3$ cells were infected and stained for $\beta$-gal and Akt. Normally, 3T3 cells express relatively low levels of Akt immunoreactivity, but $100 \%$ of $\beta$-gal + cells expressed a high level of Akt immunoreactivity, distinguished using fluorescence intensity measurements as described for cortical cells in Figure 1. To confirm the biological activity of the viruses, 3T3 cells growing in $10 \%$ calf serum (Invitrogen) were infected with control virus, wild-type Akt- 1 virus, or dn-Akt virus and selected in G418. Confluent monolayers of G418-selected cells were rinsed in serum-free medium for $4 \mathrm{hr}$, and then stimulated with a mixture of FGF2 $(10 \mathrm{ng} / \mathrm{ml})$, EGF $(10 \mathrm{ng} / \mathrm{ml})(\mathrm{R} \&$ D Systems, Minneapolis, MN), and insulin ( $25 \mathrm{ng} / \mathrm{ml}$; Sigma, St. Louis, $\mathrm{MO})$. Thirty minutes later, lysates of the cultures were prepared for Western blot analysis (see below). Blots were probed with anti-Akt, antiphospho-Akt (Thr308), or anti-phospho-GSK-3 $\beta$ (glycogen synthase kinase-3 $\beta$ ) (Ser9) antibodies (Cell Signaling Technology, Beverly, MA), and anti-actin (Sigma). Scion Image (Frederick, MD) was used to quantify band intensity from scanned gels. The phospho-Akt antibody (Thr308) distinguishes activated Akt (Alessi et al., 1996a). The dn-Akt retrovirus contains a kinase-dead mutation in Akt, blocking endogenous Akt signaling (Franke et al., 1995). Akt is known to phosphorylate a number of proteins, including GSK-3 $\beta$, which is phosphorylated by Akt at Ser9 (Alessi et al., 1996b). Cells infected with wild-type Akt-1 or dnAkt expressed threefold to fourfold more total Akt protein (normalized to actin) than control-infected cells (data not shown). The ratio of phospho-Akt (pAkt) (Thr308) to total Akt was 2.5- to 3.5-fold greater among cells infected with Akt-1 or dn-Akt than control-infected cells (data not shown). Phospho-GSK-3 $\beta$ (Ser9) levels were 1.7-fold higher in cells infected with Akt-1 virus, compared with control-infected cells and $30 \%$ lower in cells infected with dn-Akt virus, compared with controlinfected cells (data not shown).

To determine whether the level of Akt expression achieved by viral transduction of cortical cells approximates the level of Akt expressed normally by a small subset of cortical progenitors (referred to as Akt ${ }^{\text {high }}$ cells in Fig. 1), we infected embryonic day 13.5 (E13.5) cortical explants with Akt- 1 virus and stained them $4 \mathrm{~d}$ later with antibodies to Akt and $\beta$-gal. We compared them to uninfected E13.5 cells stained with antibodies to Akt and nestin. To estimate the level of Akt expression, we measured fluorescence intensity from captured images using IP Lab software. Among the cells that expressed Akt immunoreactivity at the "high" level (defined as $>300$ arbitrary units over background), the mean fluorescence intensity was $379.6 \pm 22.7$ for uninfected E13.5 Akt ${ }^{\text {high }}$ nestin + cells, whereas the mean intensity among Akt-infected E13.5 cells was $359 \pm 10.9\left(n=11\right.$ for Akt ${ }^{\text {high }}$ uninfected cells; $n=20$ for Akt-infected cells). The level of Akt expression achieved by transduction with this retrovirus was therefore comparable to the level of Akt expressed normally by a subset of cortical progenitors.

In utero injections. Timed pregnant CD1 mice (Charles River Laboratories, Wilmington, MA) were anesthetized with Nembutal (Abbott Laboratories, Irving, TX), and three or four embryos at E10.5 were injected with virus using ultrasound imaging as described (Olsson et al., 1997; Caric et al., 2001). After 6 d, injected brains were dissected and fixed for $2 \mathrm{hr}$ in $4 \%$ paraformaldehyde (PFA)-3\% PIPES at $4^{\circ} \mathrm{C}$. Brains were rinsed in $\mathrm{PBS}$ for $1 \mathrm{hr}$ then incubated in X-gal (Molecular Probes, Eugene, OR) overnight at $37^{\circ} \mathrm{C}$. The next day, brains were rinsed in PBS and graded sucrose $(10-30 \%)$. Brains were embedded in $7.5 \%$ gelatin, frozen, and stored at $-80^{\circ} \mathrm{C}$. Coronal sections were cut at $50 \mu \mathrm{m}$ (Leica, Nussloch, Germany), stained with DAPI (Molecular Probes), and visualized with a Leica DMR microscope using bright-field and fluorescence optics. All infected cells in the dorsolateral cortex, dentate gyrus, and olfactory bulb were counted. For analysis of laminar position, the cortex was divided into seven layers, the dentate gyrus was divided into four layers, and the olfactory bulb was divided into three layers, as noted in Figure 2 and described previously (Caric et al., 2001). The percentage of cells in each layer of the regions noted was calculated for each brain. In the dorsolateral cortex, 350 control-infected cells (three brains) and 436 Akt-1-infected cells (five brains) were counted. In the hippocampus, 173 control-infected cells and 525 Akt-1-infected cells were counted. In the olfactory bulb, 25 control-infected cells and 47 Akt-1-infected cells were counted. Data represents mean \pm SEM. Significance of differences was determined using a Mann-Whitney $U$ test, with $p<0.05$ considered significant.

Cell culture. E13.5 embryos from CD1 (Charles River Laboratories) or p21(Cip1)-null mice (Deng et al., 1995) (The Jackson Laboratory, Bar Harbor, ME) were used to prepare cortical explants. p21(Cip1)-null mice were maintained on a B6129SF2/J background and genotyped by PCR. All animal studies were approved by the University of Pittsburgh Institutional Animal Care and Use Committee. Crown-rump length and external features were used to determine the developmental stage of the embryos (Theiler, 1972). The dorsolateral cortex was dissected and placed ventricular side down on a Nucleopore filter $(13 \mathrm{~mm}, 0.2 \mu \mathrm{m}$; Corning, Corning, NY; Fisher Scientific, Pittsburgh, PA) floating in serum-free N2 medium (Bottenstein and Sato, 1979) containing 25 $\mu \mathrm{g} / \mathrm{ml}$ insulin (Sigma). We added $20-30 \mu \mathrm{l}$ of medium containing retrovirus to the explants. After $4 \mathrm{~d}$ in culture, explants were dissociated and either stained with antibodies (see below) or cultured in mitogens in a clonogenic "neurosphere" assay for self-renewal (see below). For experiments addressing the role of mTOR, rapamycin ( $20 \mathrm{~nm}$; Cell Signaling Technology) or methanol (Sigma) was added to explant cultures daily for $3 \mathrm{~d}$, beginning $1 \mathrm{~d}$ after infection; rapamycin was not present in subsequent neurosphere cultures. To assess proliferation by incorporation of bromodeoxyuridine (BrdU), $10 \mu \mathrm{M} \mathrm{BrdU}$ (Sigma) was added to the explant cultures during the last $24 \mathrm{hr}$ ( $4 \mathrm{~d}$ in culture total); incorporation was then determined immunocytochemically (see below). For assays of migration, E13.5 cortical explants were cultured on nucleopore filters, infected with control or Akt-1 retroviruses, and treated with the combination of FGF2 and EGF for $3 \mathrm{~d}$, beginning $1 \mathrm{~d}$ after infection. These factors were added to both the medium under and above the filters. In the absence of these factors, cells remain within the explants and migrate from the ventricular zone to the cortical plate (Caric et al., 2001), but in their presence, cells migrate out of the explants onto the filters (see Fig. $3 G, H)$. To quantify the extent of their migration, we measured the distance of virally marked cells from the edge of the explant, visualizing infected cells by X-gal histochemistry (Molecular Probes). We counted 379 Akt-infected and 489 control-infected cells from eight explants per condition.

Immunocytochemistry. To stain sections of E16.5 mouse cortex, brains were dissected and fixed for $2 \mathrm{hr}$ at $4^{\circ} \mathrm{C}$ in $4 \%$ PFA in $0.1 \mathrm{M}$ phosphate buffer. Tissue was rinsed in PBS, cryoprotected in graded sucrose (10$30 \%$ ), frozen, and sectioned at $20 \mu \mathrm{m}$. Coronal sections were incubated in primary antibodies (pan-Akt or Akt-1, see below) overnight at $4^{\circ} \mathrm{C}$; secondary antibody was applied at room temperature for $2 \mathrm{hr}$. For controls, primary antibody was omitted. Sections were stained with DAPI (Molecular Probes) to distinguish nuclei. Dissociated cells were plated on poly-D-lysine-coated (Sigma) slides for $1 \mathrm{hr}$, then fixed for $10 \mathrm{~min}$ with $4 \%$ PFA in $0.1 \mathrm{M}$ phosphate buffer or 3\% PIPES buffer at room temperature. After 10 min in block (10\% FBS and 0.1\% Triton X-100 in PBS), cells were incubated in primary antibody in blocking solution for $1 \mathrm{hr}$ at room temperature. Primary antibodies included: rabbit anti- $\beta$-gal (Cor- 
tex Biochem, Inc., San Leandro, CA), mouse anti- $\beta$-gal (Promega, Madison, WI), chicken anti-GFP (Chemicon, Temecula, CA), mouse antiTuJ1 (Covance, Philadelphia, PA), mouse anti-S100 $\beta$ (Sigma), mouse anti-GFAP (Sigma), rabbit anti-NG2 (Chemicon), mouse anti-PCNA (proliferating cell nuclear antigen) (Sigma), mouse anti-BrdU (Sigma), rabbit anti-phospho-GSK-3 $\beta$ (Ser9; Cell Signaling Technology), rabbit anti-Akt (Cell Signaling Technology), rabbit anti-Akt-1 (Calbiochem, La Jolla, CA), rabbit anti-activated caspase 3 (Biovision, Mountain View, CA); mouse anti-SSEA-1 (stage-specific embryonic antigen 1) (MC-480; Developmental Studies Hybridoma Bank, Iowa City, IA); mouse antinestin (rat 401; Developmental Studies Hybridoma Bank); mouse anti-O4 (Chemicon); rabbit anti-phospho-p70 S6 kinase (Thr389; Cell Signaling Technology). Cells were rinsed in PBS then incubated for 30 min in donkey anti-mouse Cy2 or Cy3, donkey anti-rabbit Cy2 or Cy3, or donkey anti-chicken Cy2 (Jackson ImmunoResearch, West Grove, PA), or goat anti-rabbit Alexa Fluor 350 (Molecular Probes). Cells were counted and photographed with Leica DMR or Nikon (Tokyo, Japan) Eclipse E400 microscopes using fluorescence optics, PhotoMetrics (Huntington Beach, CA) Sensys or Cool Snap digital cameras, IP Lab, and Adobe Photoshop (Adobe Systems, San Jose, CA) software. For each experiment at least 100 cells were counted per condition, unless otherwise noted. Data represent mean \pm SEM from at least three independent experiments. Significance of differences was determined by $t$ tests, with $p<0.05$ considered significant.

Fluorescence intensity was measured with IP Lab software from captured images. Values shown are in arbitrary units after subtraction of background. For confocal imaging and analysis of fluorescence intensity, we used an Olympus FV300 Confocal Scanning microscope. For sections of E16.5 mouse, we collected $1 \mu \mathrm{m}$ confocal images and assessed the intensity of staining in apical and basal cytoplasm in 81 cells from three embryos. For each embryo, cells within in a 50- $\mu \mathrm{m}$-wide, $100-\mu \mathrm{m}$-high, $4 \times 1 \mu \mathrm{m}$ stack that included the ventricular surface and most of the ventricular zone were analyzed. For dissociated cells, fluorescence intensity of cytoplasmic staining was assessed from single $1 \mu \mathrm{m}$ confocal images from a total of 30 cells (from three different culture preparations, 10 cells per preparation).

Self-renewal assay. Dissociated cells were seeded at $5 \times 10^{4}$ cells per well in a 24 -well plate (Fisher Scientific) and cultured in serum-free medium with $25 \mu \mathrm{g} / \mathrm{ml}$ insulin (Sigma) and either $1 \mathrm{ng} / \mathrm{ml}$ of EGF (R \& D Systems) or $10 \mathrm{ng} / \mathrm{ml}$ of FGF2 (R \& D Systems) as described (Lillien and Raphael, 2000). In some experiments, cells were grown in the combination of insulin $(25 \mu \mathrm{g} / \mathrm{ml})$, EGF, $(1 \mathrm{ng} / \mathrm{ml})$ and FGF2 $(10 \mathrm{ng} / \mathrm{ml})$. After $10 \mathrm{~d}$ in these culture conditions, individual infected cells divide to generate clonal colonies of several hundred progeny, referred to as "neurospheres" (Reynolds and Weiss, 1992) (see Fig. 4D,E). The initial number of infected cells seeded was determined by X-gal histochemistry. Approximately 1 of 1000 to 1 of 500 cells were virally marked. After $10 \mathrm{~d}$, the number of neurospheres per well was counted. The proportion of infected cells that generated neurospheres was calculated by dividing the number of neurospheres derived from infected cells $(\beta$-gal + neurospheres) by the initial number of X-gal + cells per well. Note that the majority of cells in a neurosphere derived from an infected progenitor expressed the virally transduced marker gene $\beta$-gal (see Fig. 4 E). To assay self-renewal, primary colonies (neurospheres) were passaged by incubation in $0.05 \%$ Trypsin- $0.53 \mathrm{~mm}$ EDTA (Invitrogen) for $5 \mathrm{~min}$. Egg white trypsin inhibitor and DNase I (Sigma) were added, and cells were triturated. Cells were seeded at $4 \times 10^{3}$ cells per well in a 24-well plate (Fisher Scientific) with 50\% conditioned medium from neurospheres and 50\% serum-free medium containing insulin and either EGF $(1 \mathrm{ng} / \mathrm{ml})$ or FGF2 (10 ng/ml), or both EGF and FGF2. Every $4 \mathrm{~d}, 200 \mu \mathrm{l}$ of fresh medium with growth factor and insulin was added to each well. After $10 \mathrm{~d}$, the percentage of infected cells that generated secondary colonies (neurospheres) was determined as described above. Cultures were passaged again to generate tertiary colonies. Sister cultures (control vs Akt-1) were used for serial passaging. To induce differentiation, secondary and tertiary colonies were grown on $12 \mathrm{~mm}$ glass coverslips coated with matrigel (diluted 1:4; Becton Dickinson, San Jose, CA) for $5 \mathrm{~d}$ in the absence of exogenous mitogens. Cells were stained with cell-type specific markers as described above. For these experiments, infected cells were selected with G418 (100 $\mu \mathrm{g} / \mathrm{ml})$ on day 4 in primary neurosphere culture, resulting in neurosphere cultures derived almost exclusively from infected progenitors $(>85 \% \beta$-gal +$)$. This made it possible to triple label for neurons (TuJ1; mouse IgG-Cy2), astrocytes (GFAP; rabbit Alexa Fluor 350), and oligodendrocytes (O4; mouse IgM-Cy3) that were generated from the infected neurospheres.

Western blots. Infected 3T3 cells or neurospheres (derived from E13.5 cortical cells) were selected in G418 as described above. Cells were cultured for $4 \mathrm{hr}$ in serum-free, growth factor-free medium, then some cells were stimulated for 30-60 min with a mixture of FGF2 (10 ng/ml), EGF $(10 \mathrm{ng} / \mathrm{ml})$ and insulin $(25 \mu \mathrm{g} / \mathrm{ml})$, or just FGF2 $(10 \mathrm{ng} / \mathrm{ml})$ and insulin $(25 \mu \mathrm{g} / \mathrm{ml})$. These mixtures of growth factors were used because these are the factors used in the self-renewal ("neurosphere") assay. Cells were lysed in radioimmunoprecipitation assay buffer containing aprotinin, leupeptin, vanadate, and PMSF. Twelve micrograms (3T3) or $6 \mu \mathrm{g}$ (neurospheres) of total protein was loaded per lane and resolved by SDSPAGE (12.5\%). Blots were probed and analyzed as described above.

\section{Results}

\section{Akt expression is heterogeneous in cortical progenitors}

Akt-1 is expressed by most progenitors in the embryonic cortex (Owada et al., 1997), but we noted heterogeneity in the level of Akt expression among cortical cells from embryonic mice, based on differences in fluorescence intensity after staining dissociated cells with an Akt antibody that recognizes Akt-1, Akt-2, and Akt-3 ("pan-Akt") (Fig. 1A-E). At E13.5, 6\% of all cells expressed a high level of Akt immunoreactivity (Fig. $1 A$ ). The representation of $\mathrm{Akt}^{\text {high }}$ cells was greater among the progenitor population, distinguished with an antibody to nestin (Fig. $1 B$ ), suggesting that Akt expression is elevated in a subset of progenitors. Akt has been implicated in cell size regulation (Verdu et al., 1999), but the average diameter of Akt ${ }^{\text {high }}$, nestin + cells was not significantly larger than that of Akt ${ }^{\text {low }}$, nestin + cells $(10.3 \pm 0.4$ vs $9.3 \pm 0.4 \mu \mathrm{m} ; \mathrm{Akt}^{\text {high }}$ vs Akt ${ }^{\text {low }} ; n=3$ embryos; 10 cells of each per embryo).

The representation of Akt ${ }^{\text {high }}$ cells at E16.5 (Fig. 1C,D) was comparable to that observed at E13.5, suggesting that over this period of development no major change in the representation of these cells occurs. As noted at E13.5, the E16.5 progenitor population was enriched for Akt ${ }^{\text {high }}$ cells compared with total E16.5 cells (Fig. 1C,D). In vivo, cortical progenitors are located in the ventricular zone (VZ), a layer of cells surrounding the lateral ventricles. Akt ${ }^{\text {high }}$ cells were found in the VZ at E16.5 (Fig. 1E). In addition to progenitors, a subset of neurons, identified with an antibody to $\beta$-tubulin, expressed a high level of Akt (data not shown). Expression of a high level of Akt is therefore not restricted to progenitors.

To determine whether the heterogeneity in progenitor expression of Akt distinguished with a pan-Akt antibody reflected the pattern of Akt-1 expression, we used an antibody specific for Akt-1 to stain sections of E16.5 cortex, and we visualized staining with a confocal microscope. This confirmed that Akt-1 is expressed at a higher level in a subset of cortical progenitors in both apical and basal regions of their cytoplasm (Fig. $1 F-H$ ).

At E16.5, $\sim 1 \%$ of all cells in the dorsolateral cerebral cortex are Akt ${ }^{\text {high }}$, nestin + progenitors. This population is approximately the size of the stem cell population (Reynolds et al., 1992). Stem cells are enriched in cultures of "neurospheres," which are colonies of nestin + progenitors generated from a single progenitor cell by proliferation (Reynolds and Weiss, 1992, and see below). Primary neurospheres can be passaged to generate secondary neurospheres to demonstrate the presence of self-renewing stem cells. When neurospheres were prepared from explants of E13.5 cortex, the proportion of $\mathrm{Akt}^{\text {high }}$ cells was greater in primary and sec- 
ondary neurosphere colonies than in the explants from which they were derived (Fig. $1 I-N)$. The proportion of Akt-1 high cells was comparable to the proportion of Akt ${ }^{\text {high }}$ cells (Fig. 1, compare $M, N$ ).

These data raised the possibility that expression of a high level of Akt- 1 might promote a progenitor and/or stem cell state.

\section{Increasing Akt-1 in vivo promoted retention in progenitor layers}

To determine whether expression of a higher level of Akt-1 by progenitors altered their behavior, these cells were infected in utero at E10.5 with retroviruses that express wild-type Akt- 1 and the histochemical marker $\beta$-gal, or a control virus that just expresses $\beta$-gal. As noted in Materials and Methods, the level of Akt-1 expression achieved by retroviral transduction of cortical cells approximates the level observed among the subpopulation of cortical progenitors that normally expresses a higher level of Akt protein, estimated from measurements of fluorescence intensity. Six days after infection (E16.5) the fate of the progeny of infected cells in dorsolateral cortex was determined by analyzing their locations within the cerebral wall. Cells infected with a control virus were found predominantly in the cortical plate (Fig. $2 A-C$ ), their normal fate at this age. In contrast, a greater proportion of Akt-1-infected cells were found in progenitor layers, the $\mathrm{VZ}$ and subventricular zone (SVZ) (Fig. 2A,D,E). The tendency for Akt-1-infected cells to remain in progenitor layers was also seen in the dentate gyrus (Fig. $2 F$ ) and the olfactory bulb (Fig. 2G). Although we cannot distinguish stem cells among the Akt-1infected cells in the VZ and SVZ, stem cells are also located in these layers. These observations are consistent with the idea that elevated Akt promotes a progenitor state. Alternatively, retention in progenitor layers could reflect impaired migration of cells toward the cortical plate.

\section{In vitro Akt-1 enhanced proliferation and survival but did not impair migration}

To address the contributions of survival, proliferation, and migration to the apparent increase in progenitors after Akt-1 elevation in vivo, we used a cortical explant preparation. This culture preparation mimics development in vivo and facilitates manipulation of the environment (Burrows et al., 1997). To determine whether virally transduced Akt-1 promotes the survival of cortical cells, expression of activated caspase 3 , a marker of dying cells, was analyzed immunocytochemically (Janicke et al., 1998). E13.5 cortical progenitors were infected with control or Akt-1 retroviruses, and the proportion of infected cells that express activated caspase 3 was counted $4 \mathrm{~d}$ later. To distinguish effects of Akt- 1 on
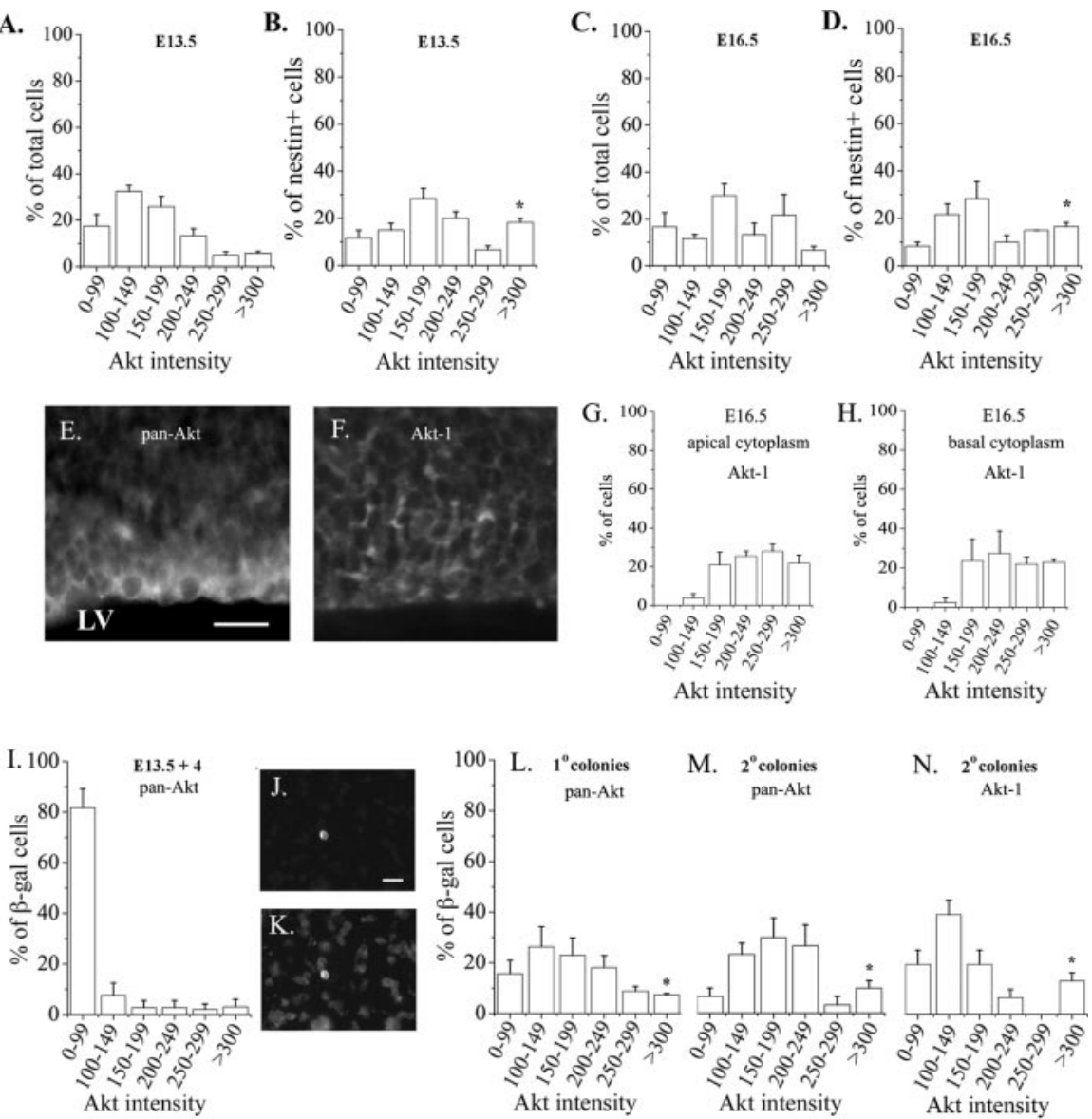

N. $2^{\circ}$ colonies

Figure 1. Heterogeneity in the level of Akt-Akt-1 expression among cortical cells. A small population of cells expressed a high level of Akt immunofluorescence at E13.5 $(A)$ and E16.5 ( $C$. The nestin + progenitor population was enriched for Akt ${ }^{\text {high }}$ cells at akt ${ }^{\text {high }}$ cells among the nestin + population to the total population ( $B$ vs $A, D$ vs $C$ ). E, F, Sections of $E 16.5$ cortex stained with 列 or Akt-1 specific $(F)$ antibodies. The micrograph in $E$ was obtained by conventional fluorescence microscopy, and the sements of fluorescence intensity in the apical $(G)$ and basal $(H)$ cytoplasm of cells within a $50-\mu \mathrm{m}$-wide, $100-\mu \mathrm{m}$ -

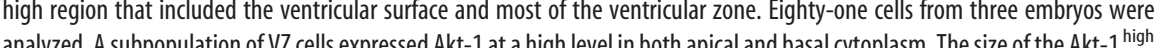
subpopulation was comparable to the Akt ${ }^{\text {high }}$ subpopulation (compare $G, H$ to D). I-K, E13.5 cortical explants were infected with control virus, and the proportion of infected cells $(\beta-\mathrm{gal}+)$ that expressed Akt immunoreactivity at distinct fluorescence levels was determined 4 d later $(I)$. Dissociated control-infected cells from an E13.5 explant stained with $\beta$-gal $(J)$ and pan-Akt ( $K$ ) was measured from confocal $1 \mu \mathrm{m}$ images. Three culture preparations were used per condition, and $10-20$ cells were counted per preparation. ${ }^{*} p<0.04$ comparing control-infected cells from primary $(L)$ or secondary $(M, N)$ neurosphere colonies to E13.5 explants $(H)$. Scale bars, $20 \mu \mathrm{m}$. the survival of neurons and progenitors, cells were triple labeled, using $\mathrm{TuJ} 1$ to identify neurons and PCNA to identify progenitors, in combination with antibodies to a viral marker (GFP) and activated caspase 3 . This revealed that Akt- 1 promoted the survival of both neurons and progenitors (Fig. $3 A$ ). The average diameter of Akt-infected cells was not different from that of controlinfected cells (10.2 \pm 2.1 vs $11.2 \pm 1.9 \mu \mathrm{m}$; control vs Akt; $n=3$, 10 cells of each per experiment).

To determine whether Akt- 1 affects the proliferation of cortical progenitors, PCNA expression was analyzed $4 \mathrm{~d}$ after infection of E13.5 progenitors. The proportion of dividing cells was greater among the Akt-1-infected population (Fig. 3B). Using BrdU incorporation to monitor proliferation, we also noted an increase 
A.
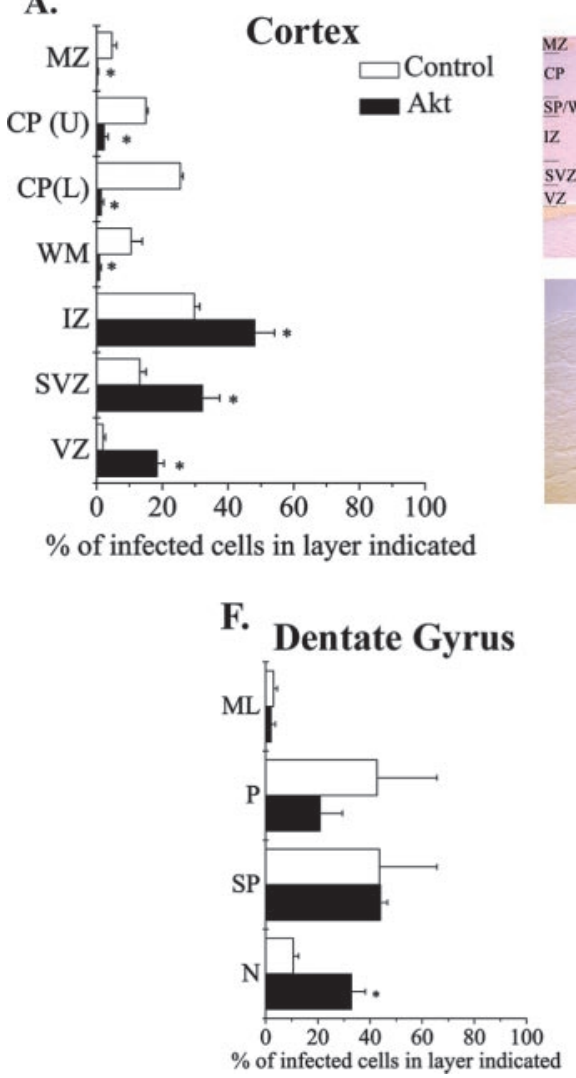

$\%$ of infected cells in layer indicated
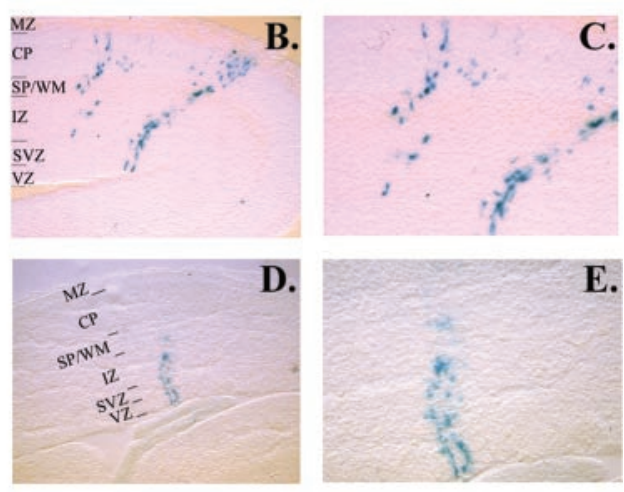

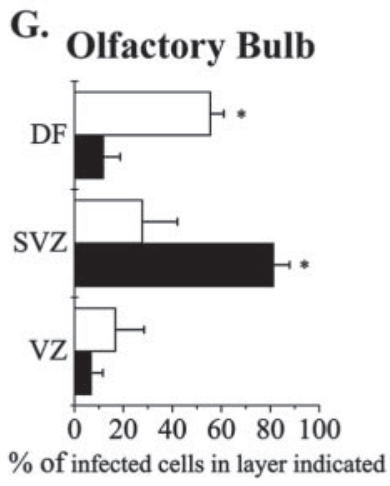

Figure 2. Elevating Akt-1 in vivo promoted retention in progenitor layers. E10.5 embryos were infected with either control or Akt-1 retroviruses. Six days later, the laminar distribution of control and Akt-1-infected cells was analyzed in the cortex $(A)$, dentate gyrus $(F)$, and olfactory bulb $(G)$. In the cortex, more Akt-1-infected cells are seen in the VZ and SVZ $(A, D, E)$ compared with control-infected cells $(A-C) . F$, In the dentate gyrus, more Akt-1-infected cells remained in the primary proliferative region $(N)$ compared with control-infected cells. $G$, In the olfactory bulb, more Akt-1-infected cells were seen in the SVZ compared with control-infected cells. $B$-E are micrographs of X-gal-stained cells in sections of $E 16.5$ cortex infected with control $(B, C)$ or $A$ kt- 1 (D, $E$ ) virus. ( and $E$ are higher-magnification images of cells shown in $B$ and $D$, respectively. ${ }^{*} p<0.05$. IZ, Intermediate zone; WM, white matter; $C P(L)$, bottom half of cortical plate; $C P(U)$ top half of cortical plate; $M Z$, marginal zone; $N$, primary proliferative layer; SP, secondary proliferative layer; $P$, dentate gyrus plate; $M L$, molecular layer, DF, differentiation field.

among the Akt-infected population: $74.7 \pm 1.8 \%$ Akt-infected cells were BrdU+, compared with $20.7 \pm 2.7 \%$ of controlinfected cells when BrdU was added for the last $24 \mathrm{hr}(n=3 ; p<$ 0.0001 ).

The proportion of neurons and astrocytes generated by cells infected with Akt-1 virus was comparable to control virus (Fig. $3 C, D)$. A small but significant increase in oligodendrocyte lineage cells was observed among Akt-1-infected cells (Fig. 3E). This is consistent with previous studies of Akt-1 regulation of oligodendrocyte lineage cells (Flores et al., 2000). The absence of large differences in cell type specification was also noted in PTEN-null mice (Groszer et al., 2001), in which Akt activity is elevated (Stambolic et al., 1998; Groszer et al., 2001). Our findings suggest that Akt-1 does not enhance proliferation by selectively increasing the proportion of mitotic glia or their progenitors. Instead, elevated expression of Akt-1 appears to promote proliferation of progenitors more generally.

Akt has been reported to alter the migration of several types of cells, including cortical neurons (Lee et al., 2001; Li et al., 2002). For example, loss of PTEN increases Akt activity, and this is associated with an increase in migration ( $\mathrm{Li}$ et al., 2002). To assay effects of elevated Akt-1 expression on migration, we infected explants of E13.5 cortex with control or Akt virus and treated them with a combination of EGF and FGF2 for $3 \mathrm{~d}$, which pro- motes migration out of explants. Infected cells were visualized by X-gal histochemistry. In the absence of these factors, virally marked cells remained within explants infected with either Akt or control virus (data not shown), as reported previously for control virus (Caric et al., 2001). In the presence of EGF and FGF2, cells migrated out of the explants, but there was no difference in the extent of migration between control and Akt virus-infected cells (Fig. $3 F-H)$. These observations favor the interpretation that elevating Akt-1 in progenitors in vivo promoted a progenitor state, rather than impairing migration.

\section{Elevated Akt-1 increased stem cells}

To address the possibility that elevated Akt regulates stem cells, progenitors in explants of E13.5 mouse cortex were infected with control or Akt-1 retroviruses. Stem cells represent a small proportion of the progenitor population in the embryonic cortex. The antigen LeX/SSEA-1 has been reported to be expressed by a population of embryonic cells enriched for stem cells (Capela and Temple, 2002). The proportion of SSEA-1+ cells was greater among cells infected with Akt-1 virus, compared with control virus $(3.8 \pm 0.4$ vs $0.3 \pm$ $0.3 \%$; Akt vs control; $n=3 ; p=0.007$ ), suggesting that Akt-1 elevation might increase the proportion of stem cells.

At the present time, it is not possible to distinguish embryonic cortical stem cells prospectively. Instead, stem cells were distinguished with a clonogenic "neurosphere" assay for self-renewal using the mitogens EGF or FGF2 and serial passaging (Reynolds and Weiss, 1992). Infected explants were dissociated after $4 \mathrm{~d}$, and the cells were cultured for an additional $10 \mathrm{~d}$ in either EGF ( $1 \mathrm{ng} / \mathrm{ml})$ or FGF2 $(10 \mathrm{ng} / \mathrm{ml})$ to allow the formation of primary colonies (neurospheres). Primary neurosphere colonies were then serially passaged to generate secondary and tertiary colonies (Reynolds and Weiss, 1992). Increasing the level of Akt-1 in a progenitor more than doubled the probability that it generates a primary (Fig. $4 A$ ), secondary (Fig. $4 B$ ), or tertiary (Fig. $4 C$ ) colony. A twofold increase in the generation of neurospheres was also observed among Akt-infected cells grown in the combination of EGF and FGF2: $65 \pm 17.6 \%$ of Akt-infected cells generated secondary neusospheres, compared with $32.7 \pm 10 \%$ of control-infected cells $(n=6 ; p=0.02)$. These observations suggest that cells expressing elevated levels of Akt are more likely to be competent to self-renew. In contrast to wild type Akt-1, if E13.5 cortical cells were infected with dnAkt (Franke et al., 1995), the proportion that exhibited self-renewal was reduced. For example, only $5.2 \pm 2.7 \%$ of cells infected with dnAkt virus generated secondary colonies in EGF, compared with $12.3 \pm 3.8 \%$ of cells infected with control virus $(n=3 ; p=0.04)$.

To confirm that the cells infected with wild type Akt-1 virus that generated neurospheres were multipotent, another feature of stem cells, secondary and tertiary colonies generated in EGF were induced to differentiate by withdrawing mitogen and allow- 
A.

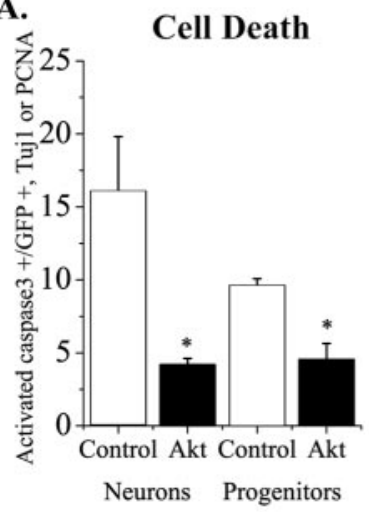

C.

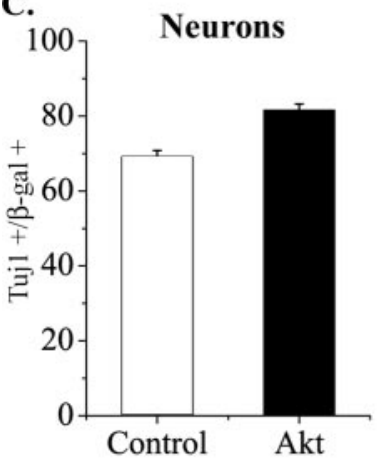

E.

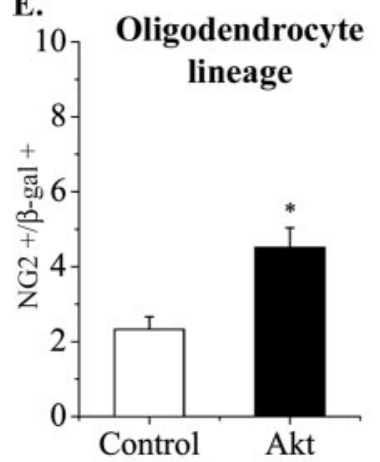

G.

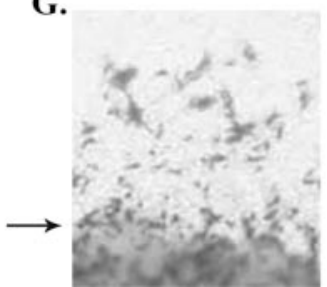

B.

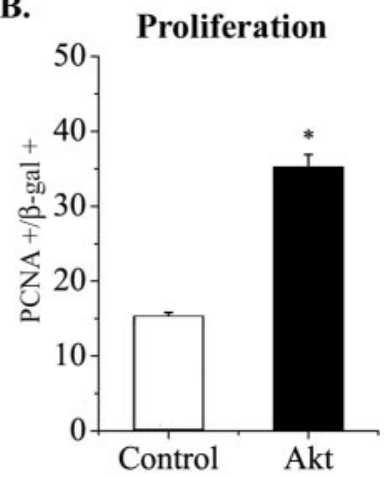

D.

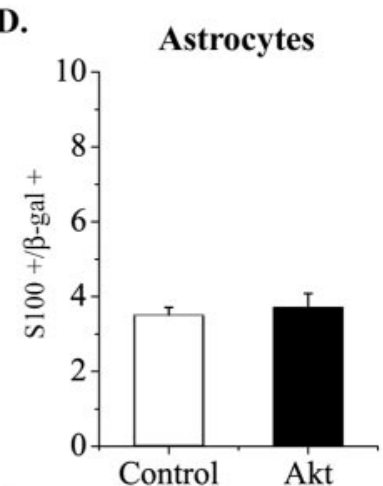

F.

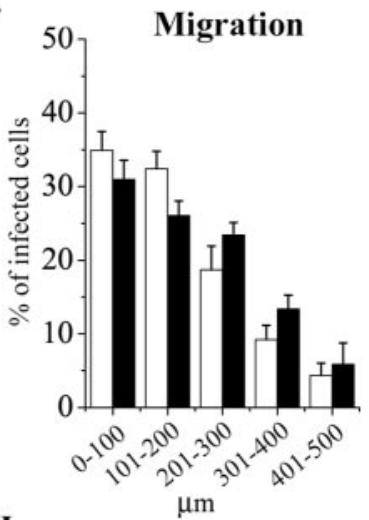

H.

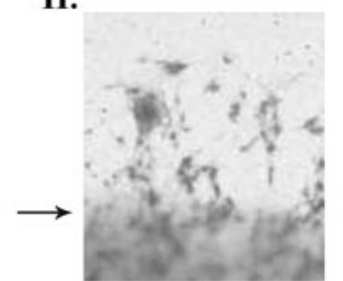

Figure 3. Elevating Akt-1 in vitro increased survival and proliferation without inducing large differences in cell fate or impairing migration. A, Progenitors in E13.5 cortical explants were infected with control or Akt-1 viruses. Four days later, cells were stained for activated caspase 3, a marker of dying cells, GFP (the viral marker) and TuJ1 (a neuron marker), or PCNA (a progenitor marker). Elevating Akt-1 reduced the proportion of activated caspase $3+$ neurons and progenitors $(A)$. Proliferation was also enhanced among the Akt-infected cells $(B)$. Akt-1 infection did not alter the generation of neurons ( $C$ ) or S-100 $\beta+$ astrocytes $(D)$. Elevating Akt- 1 caused a small, but significant increase in NG2+ (oligodendrocyte lineage) cells $(E) .{ }^{*} p<0.05$. To determine whether elevating Akt-1 impaired migration, E13.5 explants were cultured in EGF plus FGF2 for $3 \mathrm{~d}$ to stimulate migration out of explants, as shown in $G$ (control virus) and $H$ (Akt virus). Arrows indicate edges of explants. The distance of infected cells from the edges of explants was measured and found to be comparable for Akt-infected and control-infected cells $(F)$.

A.
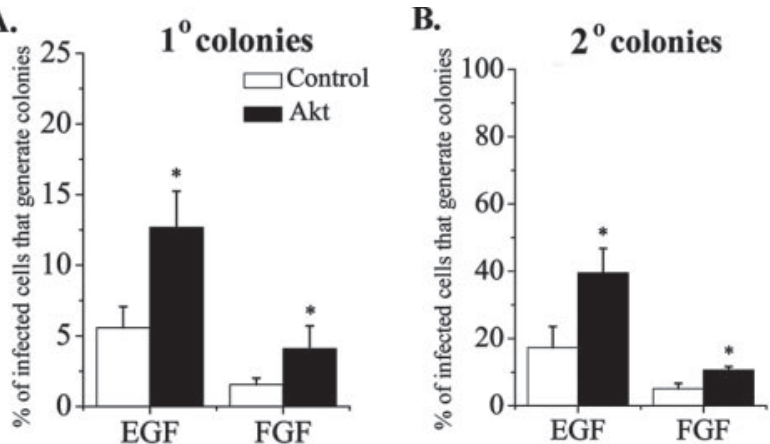

C.

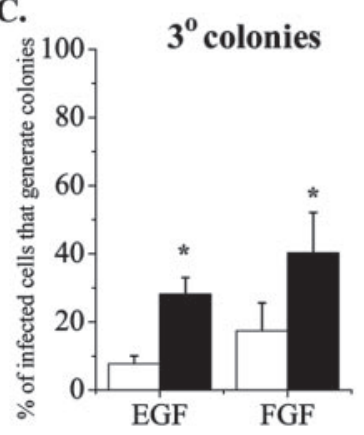

D.

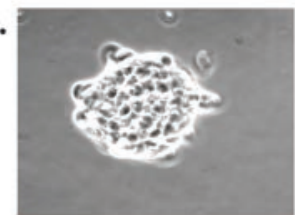

$\mathbf{E}$

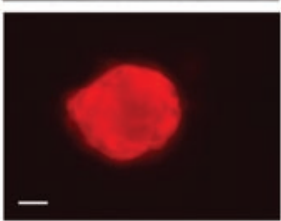

F.

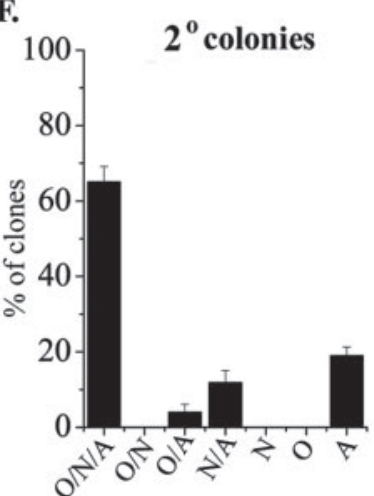

G.

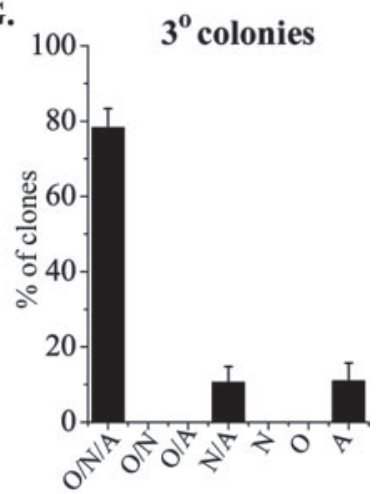

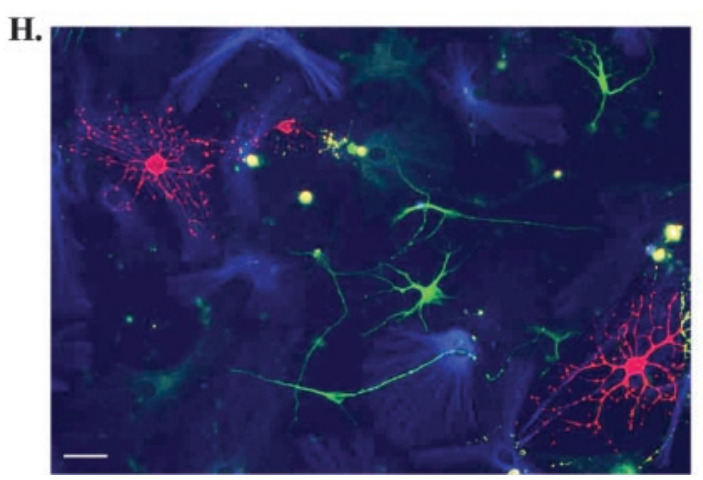

Figure 4. Elevating Akt-1 expression increased the proportion of multipotent stem cells. $A-C$, Akt-1-infected cells generated more colonies than control-infected cells after mitogen stimulation with either $\mathrm{EGF}(1 \mathrm{ng} / \mathrm{ml})$ or $\mathrm{FGF} 2(10 \mathrm{ng} / \mathrm{ml})$ in primary $(A)$, secondary $(B)$, and tertiary $(C$ cultures. $E$, A secondary neurosphere colony derived from an Akt-infected progenitor stained for $\beta$-gal; $D$ shows a phase-contrast image of this colony. Note that most of the cells in this colony expressed the virally transduced gene. To induce differentiation, Akt-1-infected secondary or tertiary neurosphere colonies were grown on matrigel for $5 \mathrm{~d}$ without exogenous mitogens. The majority of secondary $(F)$ and tertiary $(G, H)$ neurosphere colonies derived from Akt-infected progenitors are able to generate the three major cell types $(\mathrm{N} / \mathrm{A} / \mathrm{O})$, indicating derivation from a multipotent stem cell. For secondary colonies, 112 clones from three experiments were counted. For tertiary colonies, 100 clones from three experiments were counted. $N$, Neurons (TuJ $1+$ green cells in $H$ ); A, astrocytes (GFAP + blue cells in $H) ; 0$, oligodendrocytes $(04+$ red cells in $H) .{ }^{*} p<0.05$. Scale bars, $20 \mu \mathrm{m}$. 
A.

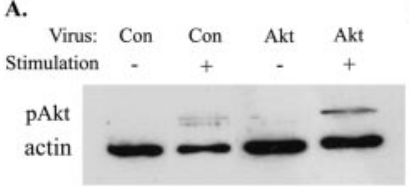

B.

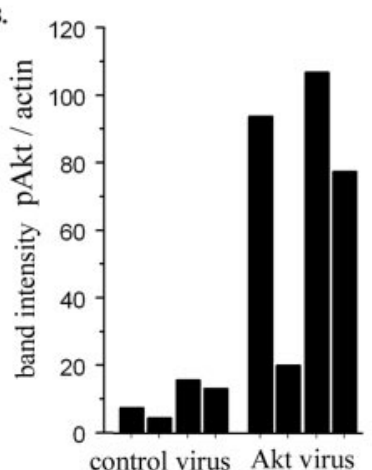

C.

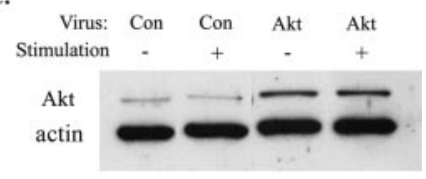

D.

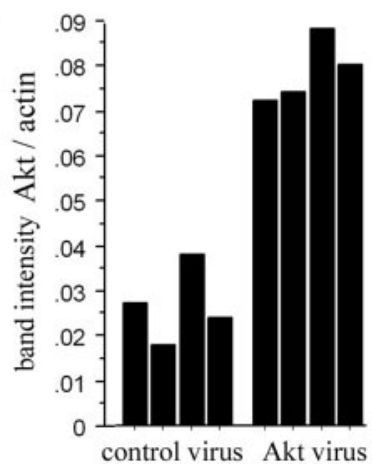

Figure 5. Elevated Akt-1 expression enhanced Akt activation. E13.5 cortical progenitors were infected with control or Akt-1 viruses, cultured in EGF, as in Figure 4, and selected in G418 to obtain cultures enriched for infected cells. After $10 \mathrm{~d}$, neurospheres were collected in serumfree, growth factor-free medium. Four hours later, half of the cells were stimulated with a mixture of EGF, FGF2, and insulin for 30-60 min. $A$, Representative Western blot, probed with antibodies to $\mathrm{pAkt}$ and actin. $B$, Summary of pAkt expression relative to actin, comparing control and Akt-infected cells in four sets of cultures. The mean difference in pAkt level (relative to actin) after stimulation was $10.2 \pm 2.5$ versus $74.4 \pm 19.1$, control-infected versus Akt-infected lysates ( $p=0.03$ ). C, Representative blot probed with Akt and actin antibodies. D, Summary of Akt expression (normalized to actin) comparing Akt-infected cells to control-infected cells in four sets of cultures. The mean difference in Akt expression (relative to actin) was $0.03 \pm 0.004$ versus $0.08 \pm 0.004$, control versus Akt ( $p=0.0003$ ).

ing cells to attach to a matrigel substratum. Five days later the cultures were stained with antibodies that distinguish the three major types of CNS cells. The majority of secondary colonies derived from Akt-infected progenitors generated neurons, astrocytes, and oligodendrocytes (Fig. $4 F$ ), confirming their derivation from multipotent progenitors. Most tertiary colonies derived from Akt-infected progenitors also generated all three cell types (Fig. 4G,H), as reported for uninfected progenitors (Reynolds et al., 1992) and observed among control-infected colonies (data not shown).

\section{Elevating Akt expression increased Akt activation}

Many of the changes in progenitor behavior seen after elevating the level of wild-type Akt-1 are similar to those reported in mice lacking the phosphatase PTEN (Groszer et al., 2001), which negatively regulates the activation of Akt (Stambolic et al., 1998). For example, PTEN-null mice have more cortical stem cells (Groszer et al., 2001). Akt activation can be distinguished immunocytochemically with an antibody to phospho-Akt (Thr308) (pAkt) (Alessi et al., 1996a). To determine whether increasing the expression of wild-type Akt alters Akt activation, we analyzed the amount of Akt, pAkt, and actin in lysates of infected cortical cells on Western blots. At 30-60 min after stimulating cortical cells with a mixture of FGF2, EGF, and insulin, expression of pAkt was elevated in control-infected and Akt-infected cells when normalized to actin (Fig. 5A), however, Akt-infected cells expressed 5- to 12-fold more pAkt than control-infected cells after stimulation (Fig. 5A,B). Akt-infected cortical cells expressed approximately twofold to fourfold more total Akt than control-infected cortical cells, when normalized to actin (Fig. 5C,D). When normalized to total Akt, the level of pAkt was approximately twofold higher in

Akt-infected cells compared with control-infected cells after stimulation. Comparable results were observed in 3T3 cells (see Materials and Methods). If cortical cells were stimulated with just the combination of FGF2 and insulin, phosphorylation of Akt (Thr308) was also twofold higher among Akt-infected cells (pAkt band intensity, normalized to actin: 0.053 for Akt-infected cells vs 0.024 for control-infected cells, $60 \mathrm{~min}$ after stimulation).

These data indicated that increasing the level of Akt-1 expression enhances the activation of Akt in response to extrinsic signals that regulate progenitor behavior. In 3T3 cells we noted that this results in an increase in Akt activity, detected with an antibody to pGSK-3 $\beta$ (Ser9), a target of Akt-1 kinase (see Materials and Methods). To confirm this in cortical cells, we stained cells with anti-pGSK-3 $\beta$ (Ser9). Elevating expression of wild-type Akt-1 increased the percentage of pGSK-3 $\beta$-positive cells compared with control-infected cells ( $81.6 \pm 3.3$ vs $50 \pm 5 \%$, Akt vs control; $n=3 ; p<0.05)$.

\section{Akt-1 does not depend on $\mathrm{p} 21(\mathrm{Cip} 1)$ to regulate progenitor or stem cells}

To begin to identify molecular mediators of Akt-1 in cortical progenitors, we examined the contribution of p21(Cip1), which is expressed in CNS stem cells (Ramalho-Santos et al., 2002) and functions downstream of Akt-1 in other types of cells (Rossig et al., 2001; Zhou et al., 2001). Explants from p21(Cip1)-null cortex were used to determine whether any of the effects of elevated Akt-1 on cortical progenitors and stem cells depend on p21(Cip1). In E13.5 explants, infection with Akt-1 virus was still able to enhance survival and proliferation in the absence of p21(Cip1) (Fig. 6A,B). Although there were fewer stem cells in p21(Cip1)-null cortex than wild-type (Fig. 6D) (compare control-infected $-/-$ to $+/+$ ), elevated Akt- 1 was still able to increase the proportion of cells that generated primary and secondary neurosphere colonies in the absence of p21(Cip1) (Fig. $6 C, D)$ (compare control vs Akt-infected $-/-$ cultures). For example, in cultures grown in FGF2, the proportion of Akt-infected cells that generate secondary colonies was $2.1 \pm 0.2$-fold greater than control-infected cells in $+/+$ cultures and $2.3 \pm 0.1$-fold greater in $-/-$ cultures $(n=3 ; p=0.6)$. Elevated Akt- 1 therefore does not require p21 (Cip1) to increase survival, proliferation, or stem cells.

\section{Akt-induced increases in stem cells and proliferation of some progenitors are rapamycin-sensitive}

mTOR, a serine-threonine protein kinase, is another substrate of the Akt-1 kinase (Sekulic et al., 2000). It is expressed in embryonic cortical cells (Hentges et al., 2001), and it is phosphorylated at the Akt site (Ser2448) in response to EGF-FGF2-insulin in control and Akt-infected cortical cells (data not shown). Akt can also increase mTOR activity indirectly by phosphorylating and inhibiting tsc2, a negative regulator of mTOR (Manning et al., 2002). To determine whether mTOR might mediate any of the responses to elevated Akt-1, we inhibited its activity pharmacologically with rapamycin (Crespo and Hall, 2002). To confirm that rapamycin treatment of cortical explants inhibits mTOR activity, infected cells were stained with an antibody that recognizes phospho-p70 S6 kinase (Thr389), a substrate of mTOR (Chung et al., 1992). Treatment with rapamycin (20 nM) reduced the proportion of control-infected and Akt-infected cells that expressed phospho-p70 S6 kinase immunoreactivity (for example, $21.6 \pm 1.8$ vs $6 \pm 0.6 \%$, methanol vs rapamycin; $n=3$ controlinfected explants; $p=0.006$ ), confirming that rapamycin inhibits mTOR in cortical cells. 

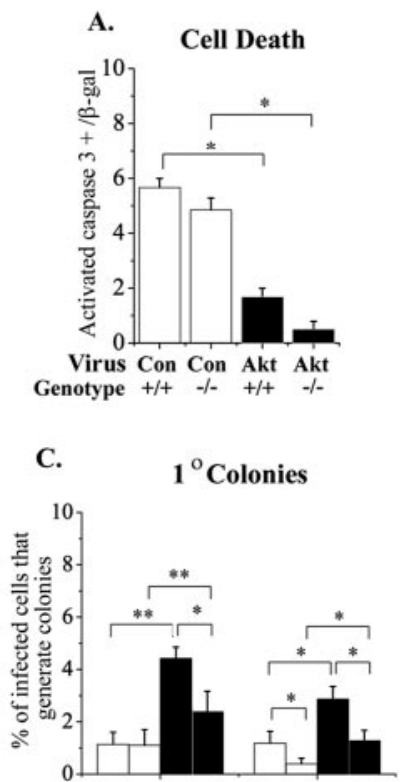

Virus Con Con Akt Akt ConConAkt Akt Genotype $+/+-1-+/+\%+/+-\%+/+\%$ Mitogen EGF
C. $\quad 1^{\circ}$ Colonies

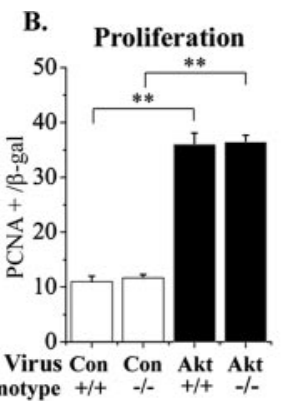

D.

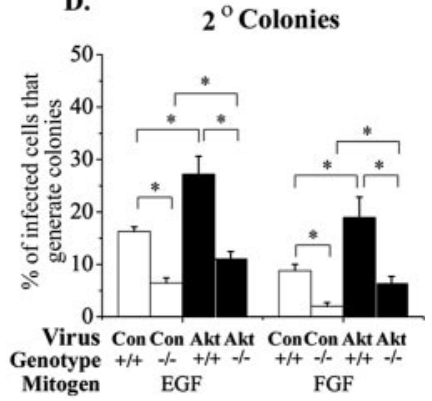

Figure 6. p21(Cip1) was not required for increased survival, proliferation, and stem cells induced by elevated Akt-1. Cortical explants from E13.5 wild-type $(+/+)$ and p21(Cip1)-null $(-/-)$ mice were infected with control or Akt-1 viruses, and the proportion of cells that expressed the cell death marker activated caspase $3(A)$ or the proliferation marker PCNA $(B)$ was counted $4 \mathrm{~d}$ later. Elevated Akt-1 still reduced death and increased proliferation in the absence of p21(Cip1). In the absence of p21(Cip1), fewer control-infected cells generated secondary neurospheres, suggesting that there are fewer CNS stem cells in the p21(Cip1)-null cortex. Even in the absence of p21(Cip1), however, elevating Akt-1 was still able to increase the proportion of cells that generate primary $(C$ and secondary $(D)$ colonies approximately twofold when compared with control-infected cells, as in cultures from wild-type cortex. ${ }^{*} p<0.05$; ${ }^{* *} p<0.009$.

In explants of E13.5 cortex, inhibiting mTOR with rapamycin did not enhance cell death among either control-infected or Aktinfected cells (Fig. 7A). Rapamycin reduced the magnitude of the change in proliferation induced by elevated Akt-1, but the increase elicited by elevated Akt-1 was still significant (Fig. 7B). This suggests that elevated Akt-1 depends on mTOR for proliferation in some but not all progenitors. In contrast to this partial dependence on mTOR, the ability of elevated Akt-1 to increase the proportion of stem cells was eliminated after treatment of explants with rapamycin (Fig. 7C,E). Note that rapamycin was not included in the stem cell assay cultures. Rapamycin also reduced the proportion of Akt-1-infected cells that express LeX/ SSEA-1 (3.8 \pm 0.4 vs $0.3 \pm 0.3 \%$, methanol vs rapamycin in E13.5 $+4 \mathrm{~d}$ explants; $n=3 ; p=0.007)$. These data support the idea that the ability of elevated Akt-1 to increase the proportion of stem cells depends on mTOR activity.

Rapamycin also inhibited the generation of primary and secondary neurosphere colonies by control-infected cells (Fig. $7 C, E)$. A reduction in the generation of neurosphere colonies was also seen among the uninfected population after treatment of explants with rapamycin (Fig. $7 D, F$ ). This suggests that mTOR activity contributes normally to the maintenance of stem cells in the embryonic CNS, although it may not be necessary for survival or proliferation in all progenitors.

\section{Discussion}

Converging data pointed to the possibility that Akt-1 might regulate the behavior of CNS progenitors. Growth factors that in-
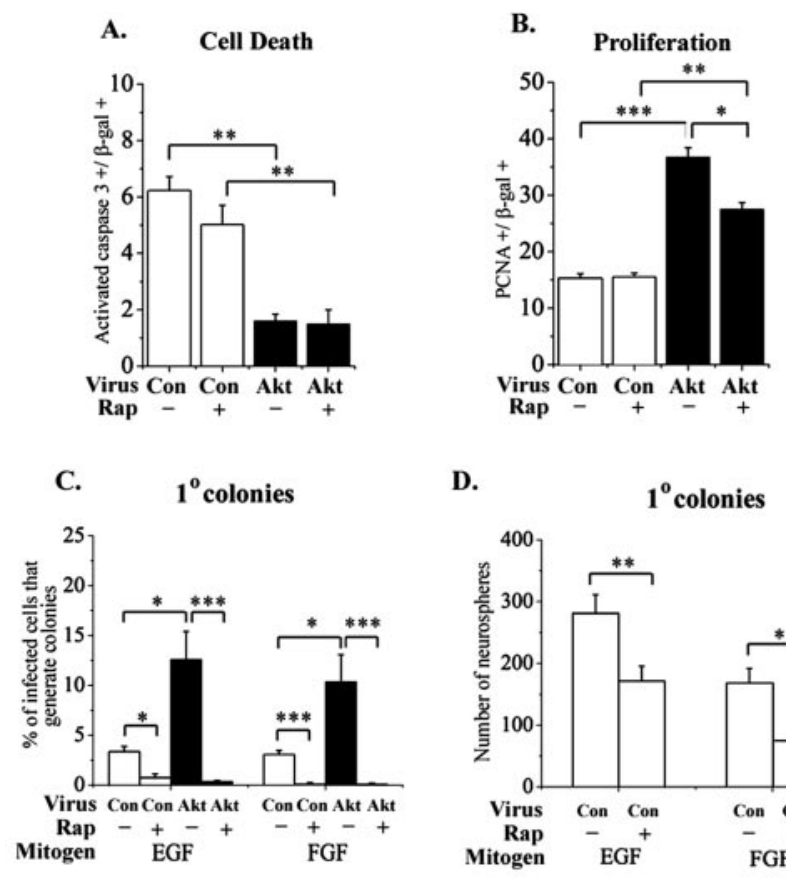

D.
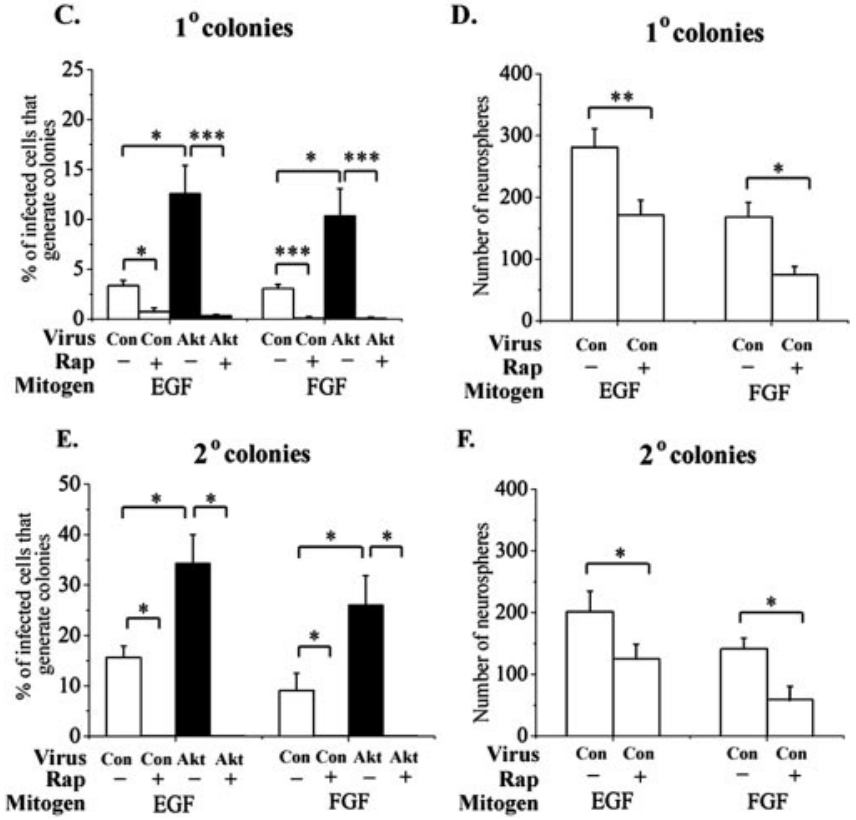

F.

$2^{\circ}$ colonies

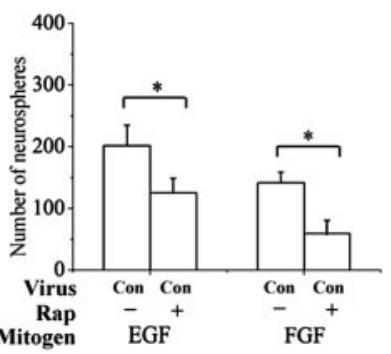

Figure 7. Rapamycin alters responses to elevated Akt-1 selectively. The mTOR inhibitor rapamycin (20 nm) was added to explants of E13.5 cortex infected with control or Akt virus. Methanol was added to control cultures. After $4 \mathrm{~d}$, there was no difference in the proportion of caspase $3+$ cells between methanol and rapamycin-treated cultures $(A)$, indicating that elevating Akt-1 can still increase survival if mTOR is inhibited. Akt-1 elevation still increased proliferation if mTOR was inhibited, although the magnitude of this effect was reduced compared with cultures grown without rapamycin $(B)$. Rapamycin treatment did not reduce proliferation in control-infected explants $(B)$. Rapamycin was removed after $3 \mathrm{~d}$ of explant exposure, and the explants were used to generate primary $(C, D)$ and secondary $(E, F)$ neurosphere colonies. Note that rapamycin was not added to neurosphere cultures. Inhibiting mTOR transiently in explants caused a lasting reduction in stem cells among control- and Akt-infected $(E)$ cells. Among the total population $(D, F)$, which is derived primarily from uninfected cells, there is also a lasting reduction in EGF-responsive and FGF2-responsive stem cells. ${ }^{*} p<0.05 ;{ }^{* *} p<0.008$; ${ }^{* * *} p<$ 0.0001 .

crease the proportion of progenitors and stem cells, such as FGF2 and EGF, activate Akt-1 (Brazil and Hemmings, 2001). PTEN, which reduces CNS stem cell number, is a negative regulator of Akt activation (Groszer et al., 2001). Although most cells in the embryonic mouse cortex express Akt-1, we noted that a subpopulation of progenitors expressed a higher level of Akt-1 protein. To determine the functional significance of this molecular difference, we increased expression of wild-type Akt-1 in cortical progenitors. We found that this enhanced survival, proliferation, and self-renewal. Akt-1 acts upstream of a number of signaling pathways, but our data suggest that the effect of elevated Akt-1 expression on stem cells involves mTOR but not p21(Cip1). In contrast, the increase in survival elicited by elevated Akt-1 does not depend on p21(Cip1) and is not sensitive to rapamycin, sug- 
gesting that it does not depend on mTOR activity. Our findings support the idea that elevated expression of Akt-1 in a subpopulation of cortical progenitors modulates their responses to extrinsic signals, favoring a progenitor-stem cell state. This could be achieved by increased survival, proliferation, and/or self-renewal.

Although some of the cells that express a high level of Akt-1 coexpress the progenitor marker nestin and are located in the ventricular zone, others coexpress a neuronal marker. A high level of Akt-1 expression is therefore not a progenitor or a stem cell marker. It has been proposed that specialized environments, or niches, may be important for maintaining stem cells (Watt and Hogan, 2000). In the developing cortex, however, stem cells and more restricted types of progenitors share a microenvironment in the ventricular zone. It is therefore likely that intrinsic heterogeneity among progenitors contributes to differences in their behavior. We showed previously that heterogeneity in the level of epidermal growth factor receptor expression allowed progenitors to interpret receptor activation in distinct ways (Lillien, 1995; Burrows et al., 1997). In the present study, the existence of a subset of progenitors that expresses a higher level of Akt-1, together with data documenting the functional impact of this difference on progenitor behavior, support the idea that elevated Akt-1 expression allows a subset of progenitors that may include stem cells to share an environment with other types of progenitors but respond differently to the same extrinsic signals.

In vivo, increasing the level of Akt-1 in progenitors with a retrovirus increased the proportions of cells that were found in progenitor layers $6 \mathrm{~d}$ after infection. In explants, elevating Akt-1 increased both survival of progenitors and proliferation, but did not inhibit migration elicited by the combination of FGF2 and EGF. Cells expressing a higher level of Akt-1 can therefore respond normally to some environmental signals that modulate migration. Although we cannot rule out the possibility that migration elicited by other environmental stimuli might be altered in these cells, the tendency for Akt-infected cells to remain in progenitor layers rather than migrating out to the cortical plate most likely reflects promotion of a progenitor state rather than impaired migration. Elevated expression of Akt-1 did not induce major changes in cell type specification (Fig. 3). This is consistent with observations in PTEN-null mice (Groszer et al., 2001), although not consistent with the report that Akt-1 promotes a neuronal fate (Vojtek et al., 2003). This discrepancy in the impact of Akt-1 on neuron generation could reflect differences between cortical progenitors and P19 cells.

Our results in vitro suggest that a high level of Akt-1 expression promotes a stem cell state in the embryonic cortex. This is consistent with a recent study of primordial germ cells, which also showed that elevating the level of Akt-1 expression increased the number of stem cells (De Miguel et al., 2002). There are several mechanisms by which stem cell number can be increased. For example, cell division patterns can be altered to generate two stem cell daughters rather than one. Alternatively, transit amplifying cells can be induced to behave like stem cells (Doetsch et al., 2002; Hitoshi et al., 2002). In the intestine, crypts are thought to contain both stem cells and a separate population of transit amplifying progenitors that are competent to behave as stem cells under appropriate environmental circumstances (Potten and Loeffler, 1990). A comparable population of stem cellcompetent, transit-amplifying cells might exist in the embryonic telencephalon. Elevating Akt-1 could confer the property of selfrenewal to such cells, causing them to behave like stem cells. In the study of primordial germ cells, it was suggested that elevation of Akt-1 acted by increasing survival (De Miguel et al., 2002). We found that elevating Akt-1 increased the survival of cortical progenitors more generally, so it is possible that increased stem cell survival contributes to the increase in the proportion of neural stem cells. We cannot distinguish which of these mechanisms is most important for the change in stem cells caused by elevating Akt-1, although it is possible that all of the above play a role.

Why should increasing the level of wild-type Akt-1 alter the behavior of a cell? In mesenchymal stem cells (Mangi et al., 2003), 3T3 cells (see Materials and Methods), and cortical progenitors (Fig. 5), increasing the level of wild-type Akt-1 increased Akt-1 activation. In this respect, higher Akt-1 expression resembles loss of PTEN, which also leads to an increase in Akt activation and an increase in CNS stem cells (Groszer et al., 2001). Akt-1 phosphorylates a number of proteins that could mediate the effects of elevated Akt-1 expression and activation in cortical progenitors. These include GSK-3 $\beta$ (Diehl et al., 1998), forkhead family genes (Brunet et al., 1999), p21(Cip1) (Zhou et al., 2001), tsc 2 (Manning et al., 2002), and mTOR (Nave et al., 1999). p21(Cip1) is expressed by several types of stem cells, including CNS stem cells (Ramalho-Santos et al., 2002), and loss of p21(Cip1) has been shown to reduce the number of hematopoetic stem cells (Cheng et al., 2000). These findings made p21(Cip1) a reasonable candidate mediator of Akt-1 in cortical progenitors. Our results show that although the number of stem cells in p21(Cip1)-null cortex is reduced, elevating Akt-1 does not require p21(Cip1) to increase the proportion of stem cells, or to enhance survival and proliferation.

Akt-1 can increase mTOR activity directly (Crespo and Hall, 2002) or indirectly, via tsc2 (Manning et al., 2002). mTOR is normally expressed by progenitors in the developing telencephalon (Hentges et al., 2001). In the mouse mutant flat-top, mTOR function in the developing telencephalon is reduced, as is proliferation (Hentges et al., 1999, 2001). A similar phenotype was observed after rapamycin treatment in utero at early stages of development (Hentges et al., 2001). We found that exposing cortical explants to rapamycin at a later stage of development did not alter the proliferation of control-infected cells. This could mean that the dependence of most cortical progenitors on mTOR for proliferation changes during development. Rapamycin caused a partial reduction in the ability of elevated Akt- 1 to increase proliferation, but did not reduce survival. These observations have several implications. First, they suggest that elevating Akt-1 does not increase the size of the progenitor population just by increasing survival. Second, they suggest that there is heterogeneity in the sensitivity of Akt-infected cells to rapamycin. It is not known what distinguishes the cells that are less sensitive to rapamycin, but they are likely to be restricted progenitors, rather than stem cells, because rapamycin completely inhibited the increase in stem cells. In most cortical progenitors, mTOR activity was not necessary for survival, at least for periods of $3 \mathrm{~d}$ in vitro. We cannot rule out the possibility that stem cells are dependant on mTOR for survival, however, because an assay of cell death would not have distinguished a reduction in such a small population.

In contrast to its more general effects on survival and proliferation, the ability of elevated Akt-1 to increase stem cells is more sensitive to rapamycin, presumably reflecting greater dependence on mTOR activity. Reducing mTOR activity transiently caused a lasting reduction in the self-renewing population of Akt-infected cells. This could reflect reduced proliferation, survival, and/or reduced capacity for self-renewal. In addition to the Akt-infected cells, the self-renewing population was also reduced among control-infected and uninfected progenitor populations. Infected cells appeared to be more sensitive to loss of mTOR 
activity than uninfected cells, but the reason for this difference is not known. In a recent study of Bmi-1-null mice, a reduction in stem cells was also observed in the absence of a general reduction in proliferation or survival (Molofsky et al., 2003). This observation and our findings are consistent with the ideas that distinct mechanisms control CNS progenitor survival, proliferation, and self-renewal, and that there is heterogeneity among the selfrenewing population with respect to their dependence on specific molecules. Alternatively, proliferation and/or survival may be controlled differently in stem cells and other types of progenitors, with some stem cells more dependent on an Akt-mTOR signaling pathway for survival and/or proliferation than are other kinds of neural progenitors.

\section{References}

Alessi DR, Andjelkovic M, Caudwell B, Cron P, Morrice N, Cohen P, Hemmings BA (1996a) Mechanism of activation of protein kinase B by insulin and IGF-1. EMBO J 15:6541-6551.

Alessi DR, Caudwell FB, Andjelkovic M, Hemmings BA, Cohen P (1996b) Molecular basis for the substrate specificity of protein kinase B; comparison with MAPKAP kinase-1 and p70 S6 kinase. FEBS Lett 399:333-338.

Arsenijevic Y, Weiss S, Schneider B, Aebischer P (2001) Insulin-like growth factor-I is necessary for neural stem cell proliferation and demonstrates distinct actions of epidermal growth factor and fibroblast growth factor-2. J Neurosci 21:7194-7202.

Bottenstein JE, Sato GH (1979) Growth of a rat neuroblastoma cell line in serum-free supplemented medium. Proc Natl Acad Sci USA 76:514-517.

Brazil DP, Hemmings BA (2001) Ten years of protein kinase B signalling: a hard Akt to follow. Trends Biochem Sci 26:657-664.

Brunet A, Bonni A, Zigmond MJ, Lin MZ, Juo P, Hu LS, Anderson MJ, Arden KC, Blenis J, Greenberg ME (1999) Akt promotes cell survival by phosphorylating and inhibiting a Forkhead transcription factor. Cell 96:857-868.

Burrows RC, Wancio D, Levitt P, Lillien L (1997) Response diversity and the timing of progenitor cell maturation are regulated by developmental changes in EGFR expression in the cortex. Neuron 19:251-267.

Capela A, Temple S (2002) LeX/ssea-1 is expressed by adult mouse CNS stem cells, identifying them as nonependymal. Neuron 35:865-875.

Caric D, Raphael H, Viti J, Feathers A, Wancio D, Lillien L (2001) EGFRs mediate chemotactic migration in the developing telencephalon. Development 128:4203-4216.

Chaudhary LR, Hruska KA (2001) The cell survival signal Akt is differentially activated by PDGF-BB, EGF, and FGF-2 in osteoblastic cells. J Cell Biochem 81:304-311.

Cheng T, Rodrigues N, Shen H, Yang Y, Dombkowski D, Sykes M, Scadden DT (2000) Hematopoietic stem cell quiescence maintained by p21cip1/ waf1. Science 287:1804-1808.

Chung J, Kuo CJ, Crabtree GR, Blenis J (1992) Rapamycin-FKBP specifically blocks growth-dependent activation of and signaling by the $70 \mathrm{kd} \mathrm{S6}$ protein kinases. Cell 69:1227-1236.

Crespo JL, Hall MN (2002) Elucidating TOR signaling and rapamycin action: lessons from Saccharomyces cerevisiae. Microbiol Mol Biol Rev 66:579-591.

De Miguel MP, Cheng L, Holland EC, Federspiel MJ, Donovan PJ (2002) Dissection of the c-Kit signaling pathway in mouse primordial germ cells by retroviral-mediated gene transfer. Proc Natl Acad Sci USA 99:10458-10463.

Deng C, Zhang P, Harper JW, Elledge SJ, Leder P (1995) Mice lacking p21CIP1/WAF1 undergo normal development, but are defective in G1 checkpoint control. Cell 82:675-684.

Diehl JA, Cheng M, Roussel MF, Sherr CJ (1998) Glycogen synthase kinase3beta regulates cyclin D1 proteolysis and subcellular localization. Genes Dev 12:3499-3511.

Doetsch F, Petreanu L, Caille I, Garcia-Verdugo J, Alvarez-Buylla A (2002) EGF converts transit-amplifying neurogenic precursors in the adult brain into multipotent stem cells. Neuron 36:1021-1034.

Dudek H, Datta SR, Franke TF, Birnbaum MJ, Yao R, Cooper GM, Segal RA, Kaplan DR, Greenberg ME (1997) Regulation of neuronal survival by the serine-threonine protein kinase Akt. Science 275:661-665.

Flores AI, Mallon BS, Matsui T, Ogawa W, Rosenzweig A, Okamoto T, Mack- lin WB (2000) Akt-mediated survival of oligodendrocytes induced by neuregulins. J Neurosci 20:7622-7630.

Franke TF, Yang SI, Chan TO, Datta K, Kazlauskas A, Morrison DK, Kaplan DR, Tsichlis PN (1995) The protein kinase encoded by the Akt protooncogene is a target of the PDGF-activated phosphatidylinositol 3-kinase. Cell 81:727-736.

Geschwind DH, Ou J, Easterday MC, Dougherty JD, Jackson RL, Chen Z, Antoine H, Terskikh A, Weissman IL, Nelson SF, Kornblum HI (2001) A genetic analysis of neural progenitor differentiation. Neuron 29:325-339.

Groszer M, Erickson R, Scripture-Adams DD, Lesche R, Trumpp A, Zack JA, Kornblum HI, Liu X, Wu H (2001) Negative regulation of neural stem/ progenitor cell proliferation by the Pten tumor suppressor gene in vivo. Science 294:2186-2189.

Haseyama Y, Sawada K, Oda A, Koizumi K, Takano H, Tarumi T, Nishio M, Handa M, Ikeda Y, Koike T (1999) Phosphatidylinositol 3-kinase is involved in the protection of primary cultured human erythroid precursor cells from apoptosis. Blood 94:1568-1577.

Hentges K, Thompson K, Peterson A (1999) The flat-top gene is required for the expansion and regionalization of the telencephalic primordium. Development 126:1601-1609.

Hentges KE, Sirry B, Gingeras AC, Sarbassov D, Sonenberg N, Sabatini D, Peterson AS (2001) FRAP/mTOR is required for proliferation and patterning during embryonic development in the mouse. Proc Natl Acad Sci USA 98:13796-13801.

Hitoshi S, Alexson T, Tropepe V, Donoviel D, Elia AJ, Nye JS, Conlon RA, Mak TW, Bernstein A, van der Kooy D (2002) Notch pathway molecules are essential for the maintenance, but not the generation, of mammalian neural stem cells. Genes Dev 16:846-858.

Janicke RU, Sprengart ML, Wati MR, Porter AG (1998) Caspase-3 is required for DNA fragmentation and morphological changes associated with apoptosis. J Biol Chem 273:9357-9360.

Kilpatrick TJ, Bartlett PF (1993) Cloning and growth of multipotential neural precursors: requirements for proliferation and differentiation. Neuron 10:255-265.

Lee MJ, Thangada S, Paik JH, Sapkota GP, Ancellin N, Chae SS, Wu M, Morales-Ruiz M, Sessa WC, Alessi DR, Hla T (2001) Akt-mediated phosphorylation of the $\mathrm{G}$ protein-coupled receptor EDG-1 is required for endothelial cell chemotaxis. Mol Cell 8:693-704.

Li DM, Sun H (1998) PTEN/MMAC1/TEP1 suppresses the tumorigenicity and induces G1 cell cycle arrest in human glioblastoma cells. Proc Natl Acad Sci USA 95:15406-15411.

Li L, Liu F, Salmonsen RA, Turner TK, Litofsky NS, Di Cristofano A, Pandolfi PP, Jones SN, Recht LD, Ross AH (2002) PTEN in neural precursor cells: regulation of migration, apoptosis, and proliferation. Mol Cell Neurosci 20:21-29.

Lillien L (1995) Changes in retinal cell fate induced by overexpression of EGF receptor. Nature 377:158-162.

Lillien L, Raphael H (2000) BMP and FGF regulate the development of EGFresponsive neural progenitor cells. Development 127:4993-5005.

Luo Y, Cai J, Liu Y, Xue H, Chrest FJ, Wersto RP, Rao M (2002) Microarray analysis of selected genes in neural stem and progenitor cells. J Neurochem 83:1481-1497.

Mangi AA, Noiseux N, Kong D, He H, Rezvani M, Ingwall JS, Drau V (2003) Mesenchymal stem cells modified with Akt prevent remodeling and restore performance of infarcted hearts. Nat Med 9:1195-1201.

Manning BD, Tee AR, Logsdon MN, Blenis J, Cantley LC (2002) Identification of the tuberous sclerosis complex-2 tumor suppressor gene product tuberin as a target of the phosphoinositide 3-kinase/akt pathway. Mol Cell 10:151-162.

Molofsky AV, Pardal R, Iwashita T, Park IK, Clarke MF, Morrison SJ (2003) Bmi-1 dependence distinguishes neural stem cell self-renewal from progenitor proliferation. Nature 425:962-967.

Nakamura N, Ramaswamy S, Vazquez F, Signoretti S, Loda M, Sellers WR (2000a) Forkhead transcription factors are critical effectors of cell death and cell cycle arrest downstream of PTEN. Mol Cell Biol 20:8969-8982.

Nakamura Y, Sakakibara S, Miyata T, Ogawa M, Shimazaki T, Weiss S, Kageyama R, Okano H (2000b) The bHLH gene hesl as a repressor of the neuronal commitment of CNS stem cells. J Neurosci 20:283-293.

Nave BT, Ouwens M, Withers DJ, Alessi DR, Shepherd PR (1999) Mammalian target of rapamycin is a direct target for protein kinase B: identifica- 
tion of a convergence point for opposing effects of insulin and amino-acid deficiency on protein translation. Biochem J 344:427-431.

Olsson M, Campbell K, Turnbull DH (1997) Specification of mouse telencephalic and mid-hindbrain progenitors following heterotopic ultrasound-guided embryonic transplantation. Neuron 19:761-772.

Owada Y, Utsunomiya A, Yoshimoto T, Kondo H (1997) Expression of mRNA for Akt, serine-threonine protein kinase, in the brain during development and its transient enhancement following axotomy of hypoglossal nerve. J Mol Neurosci 9:27-33.

Potten CS, Loeffler M (1990) Stem cells: attributes, cycles, spirals, pitfalls and uncertainties. Lessons for and from the crypt. Development 110:1001-1020.

Ramalho-Santos M, Yoon S, Matsuzaki Y, Mulligan RC, Melton DA (2002) "Stemness": transcriptional profiling of embryonic and adult stem cells. Science 298:597-600.

Ray J, Peterson DA, Schinstine M, Gage FH (1993) Proliferation, differentiation, and long-term culture of primary hippocampal neurons. Proc Natl Acad Sci USA 90:3602-3606.

Reynolds BA, Weiss S (1992) Generation of neurons and astrocytes from isolated cells of the adult mammalian central nervous system. Science 255:1707-1710.

Reynolds BA, Tetzlaff W, Weiss S (1992) A multipotent EGF-responsive striatal embryonic progenitor cell produces neurons and astrocytes. J Neurosci 12:4565-4574.

Rossig L, Jadidi AS, Urbich C, Badorff C, Zeiher AM, Dimmeler S (2001) Akt-dependent phosphorylation of p21(Cip1) regulates PCNA binding and proliferation of endothelial cells. Mol Cell Biol 21:5644-5657.

Sekulic A, Hudson CC, Homme JL, Yin P, Otterness DM, Karnitz LM, Abraham RT (2000) A direct linkage between the phosphoinositide 3-kinaseAKT signaling pathway and the mammalian target of rapamycin in mitogen-stimulated and transformed cells. Cancer Res 60:3504-3513.
Shingo T, Sorokan ST, Shimazaki T, Weiss S (2001) Erythropoietin regulates the in vitro and in vivo production of neuronal progenitors by mammalian forebrain neural stem cells. J Neurosci 21:9733-9743.

Stambolic V, Suzuki A, de la Pompa JL, Brothers GM, Mirtsos C, Sasaki T, Ruland J, Penninger JM, Siderovski DP, Mak TW (1998) Negative regulation of PKB/Akt-dependent cell survival by the tumor suppressor PTEN. Cell 95:29-39.

Sun H, Lesche R, Li DM, Liliental J, Zhang H, Gao J, Gavrilova N, Mueller B, Liu X, Wu H (1999) PTEN modulates cell cycle progression and cell survival by regulating phosphatidylinositol 3,4,5,-trisphosphate and Akt/protein kinase B signaling pathway. Proc Natl Acad Sci USA 96:6199-6204.

Temple S (2001) The development of neural stem cells. Nat Rev Neurosci 2:513-520.

Theiler K (1972) The house mouse. New York: Springer.

Verdu J, Buratovich MA, Wilder EL, Birnbaum MJ (1999) Cell-autonomous regulation of cell and organ growth in Drosophila by Akt/PKB. Nat Cell Biol 1:500-506.

Viti J, Feathers A, Phillips J, Lillien L (2003) Epidermal growth factor receptors control competence to interpret leukemia inhibitory factor as an astrocyte inducer in developing cortex. J Neurosci 23:3385-3393.

Vojtek AB, Taylor J, DeRuiter SL, Yu JY, Figueroa C, Kwok RP, Turner DL (2003) Akt regulates basic helix-loop-helix transcription factorcoactivator complex formation and activity during neuronal differentiation. Mol Cell Biol 23:4417-4427.

Watt FM, Hogan BL (2000) Out of Eden: stem cells and their niches. Science 287:1427-1430.

Zhou BP, Liao Y, Xia W, Spohn B, Lee MH, Hung MC (2001) Cytoplasmic localization of p21Cip1/WAF1 by Akt-induced phosphorylation in HER2/neu-overexpressing cells. Nat Cell Biol 3:245-252. 